\title{
ON THE LEAF CELL MEASUREMENTS IN MOSSES
}

\author{
ОБ ИЗМЕРЕНИЯХ КЛЕТОК ЛИСТА У МХОВ \\ OLEG V. IVANOV \& MichaEL S. IGNATOV \\ ОЛЕГ В. ИВАНОВ, МИХАИЛ С. ИГНАТОВ
}

Abstract

The newly developed method of cell net digitizing is applied to illustrate variation in leaf cell length, width and square on the example of two moss species, Mnium spinosum and M. spinulosum. The accuracy of the literature data is tested by use of a large array of computerized measurements.

Резюме

Новый разработанный авторами метод оцифровки клеточной сети использован для измерения длины, ширины и площади клеток листовой пластинки мхов, на примере Mnium spinosum и M. spinulosum. Точность литературных указаний проверяется на больших массивах компьютеризированных измерений.

KEYWORDS: mosses, leaf cells, digitizing, measurements, Mnium, morphology, polarized microscopy

\section{INTRODUCTION}

Since the early days of bryology, the leaf cell nets were in the focus of studies. The areolationpatterns are reflected in such moss species epithets as "angustirete", "brevirete", "densirete", laxirete", etc. The outlines of laminal cells became a standard element of species descriptions in the middle of the XIX century, although the areolation in some species is given already in the colored illustrations in 'Species Muscorum' (Hedwig , 1801). Since the end of the XIX century (e.g. Lindberg \& Arnell, 1890; Limpricht, 18851904 , etc.) cell size has become an ordinary and important part of species description.

The length and width of cells are a common element of morphological description nowadays (Crum \& Anderson, 1981; Smith, 2004; Ignatov \& Ignatova, 2003-2004; Noguchi, 1989, 1992 , etc.), however values provided by different authors for the same species sometimes vary greatly, cf. Table 1. Some authors report values for cell width consistently lower than others, likely because of measuring only the cell lumen width or otherwise measuring a fixed distance, say 50 or $100 \mu \mathrm{m}$, and then dividing it by a number of cells crossing it.

Most publications provide laminal cell length and width without any special definition as a selfevident one. Only few papers and manuals explain explicitly what and where has to be measured to obtain the data comparable with those of other authors (Hedenäs, 1993; 2003; Ignatov \& Ignatova, 2003-2004).

A recently developed method of cell net digitizing (Ivanov \& Ignatov, to e published) has opened new possibilities for measurements on large massifs of data, and its possible usefulness for bryology will be illustrated here by some examples.

\section{MATERIAL AND METHODS}

Microscopy: The study is conducted with a polarized microscope (modified ordinary light microscope) where two polarizing filters are rotatable, while a specimen is immobile. The first

1 - P.N. Lebedev' Institue of Physics of Russ. Acad. Sci., Leninsky 53, Moscow 119991 Russia - Россия 119991, Москва, Ленинский проспект, 53, ФИАН, e-mail: ivanov@td.lpi.ru

2 - Main Botanical Garden, Russian Academy of Sciences, Botanicheskaya 4, Moscow 127276 Russia - Москва 127276, Ботаническая 4, ГБС РАН, e-mail: misha_ignatov@list.ru 
Table 1. Comparison of published data on cell width in five pleurocarpous moss species, in $\mu \mathrm{m}$.

Noguchi (1992) Smith (2004) Latwon (1971) Limpricht Ignatov \&

Ptilium crista-castrensis

Callicaldium haldanianum

Calliergonella lindbergii

Isopterygiopsis muelleriana

Hylocomium splendens

2
$4-4.5$
$3-4$
$4-4.5$
$3-4$

4-5

$-$

$5.0-6.5$

4-6

$5-7$

(1885-1904) Ignatova (2004)

3-5
$5-7$
$4-7$
-
$4-6$

5

4-6

5-8

5-7

6-7

$-$

5-6

5

$5-6$

filter (called polarizer) is placed in front of the condenser. The second one (called analyzer) stands after the objective These filters are rotated in such a way as to ensure a maximally dark field when the specimen is absent. The polarized light induced in this way allows the "staining" of cell walls (Fig. 1). The complete 'staining' of all cell walls is achieved through a combination of three digital photographs by simultaneous rotation of both filters at angles of $30^{\circ}, 60^{\circ}$ and $90^{\circ}$ (Fig. 1B-D).

Digitizing: The algorithm for finding cell walls searches maximally bright places between darker inner parts of cells and then it fixes the cell corners (join points of 3 or more cells); the next step involves digitized nets where corners of each cell are connected by straight lines (Fig. 1E). This simplification does not affect much the accuracy in such analyses of images with 6001300 cells per picture (to be published), at least in cases where the cell length to width ratio is less than 3-4:1.

The piloted program generally failed to recognize only a trace amount of cells, especially those damaged by fungi, or broken in the course of specimen preparation. Figs. 1-3, 5 have a few areas where not all cells are recognized, although the program often provides one hundred percent recognition (Fig. 4). This program require UNIX operation system; is can be obtained for free upon agreement from the authors (inquire by e-mail). Its detailed description is given in Ivanov \& Ignatov (submitted for publication).

Leaf study: Individual photographs (example in Figs. 2-4) were taken in order from lower part of leaf (however excluding basal part with obviously elongate cells) towards leaf apex considering minimal overlapping with previous picture, and in broad leaves by two (closer to costa and then closer to margin) at the same distance from base. Examples of raw data shown in Tables 3-4.

Width and length are trivial dimensions in a quadrate-rectangular cell net, e.g., in a wellknown cosmopolitan Ceratodon purpureus, while already in Tortula mucronifolia, which has cells 'more or less' close to a quadrate shape, the measurement procedure is not so straightforward (Fig. 1). There exists a temptation to provide a calculation of length as a difference between coordinates of the upper and lower points, and similarly of width for coordinates in the direction perpendicular to length. This method however fails to work for cells in oblique rows like in, e.g., many Mniaceae, where a diagonal could be measured instead of length, and all this occurs due to the unsolved problem of length definition.

To avoid these ambiguities, we defined the cell length and width as the length of, correspondingly, a longer and a shorter side of the minimal rectangular outlining the cell contour. The program of finding this minimal rectangular is simple enough and can be applied to a cell of any shape in any part of a leaf. An illustration of how it works is given in Fig. $1 \mathrm{G}$.

For further testing if this method can be used for bryological purposes, we compare two species of Mnium, M. spinosum and M. spinulosum, because several authors have published quite different dimensional characteristics for their cells (Table 2). They can be clearly distinguished from each other by sexual condition, dioicous and synoicous

Fig. 1. Tortula mucronifolia (from: Yakutia, Ignatov, 00-368, MHA). A - cell net in transmitted light; B, C, $\mathrm{D}$ - photographps in polarized light at $30^{\circ}, 60^{\circ}$ and $90^{\circ}, \mathrm{E}-$ sum of $\mathrm{B}+\mathrm{C}+\mathrm{D}$, with digitized cell outlines; $\mathrm{F}-$ digitized cell net over photo in transmitted light (cf. A); $\mathrm{G}$ - digitized cell net with rectangulars outlining each cells (G' - magnified part of G). Scale bar $300 \mu \mathrm{m}$ for A-E. 

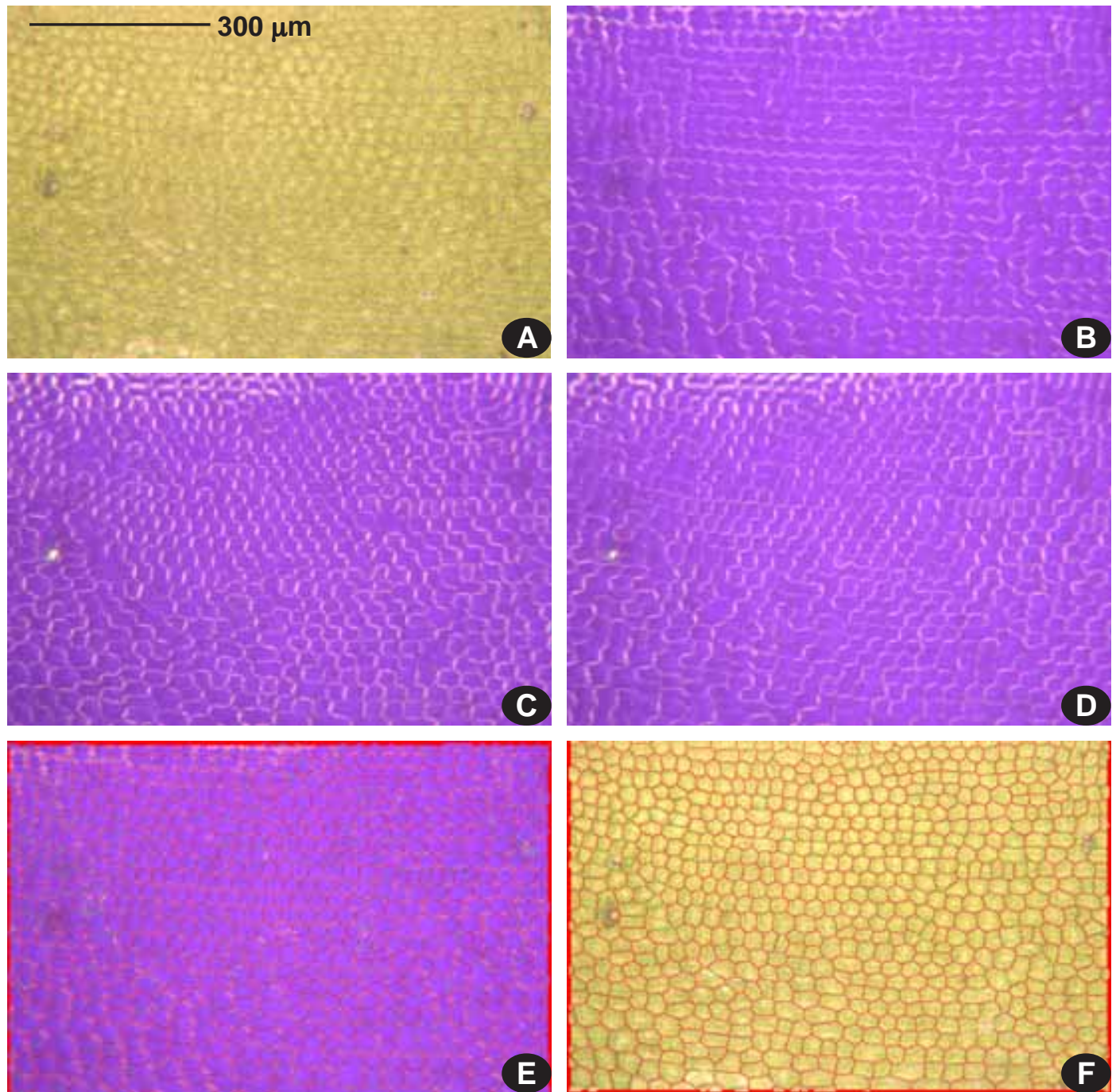

'26d'

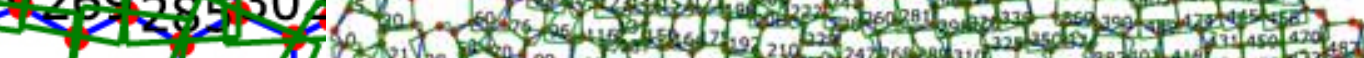

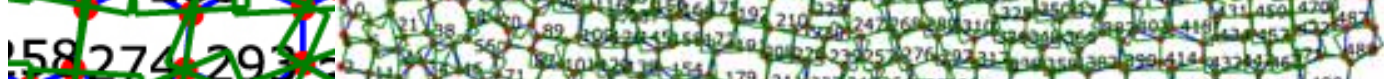

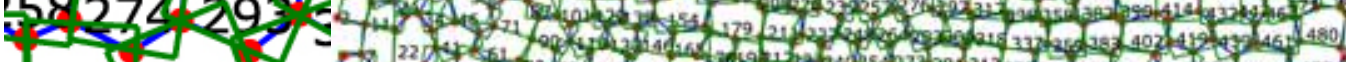

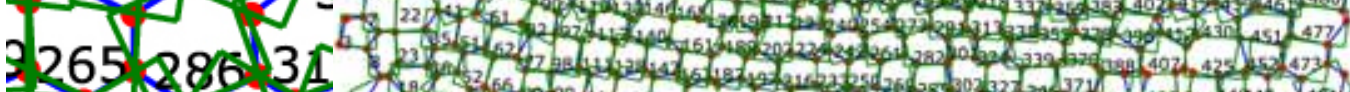

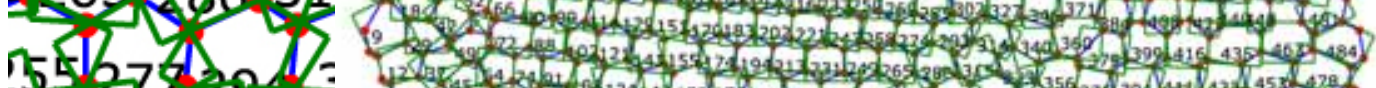
$35273 x+4=$ 4

$-1 / 30$

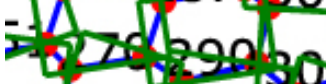

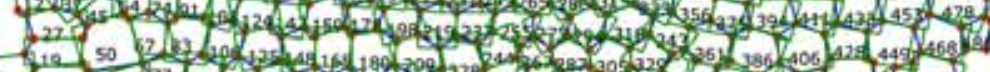

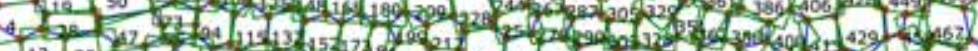

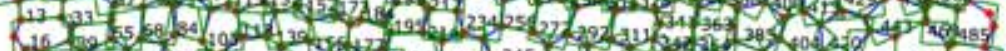

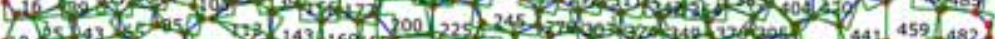

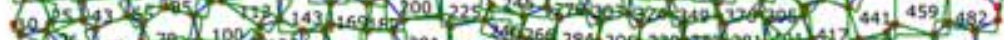

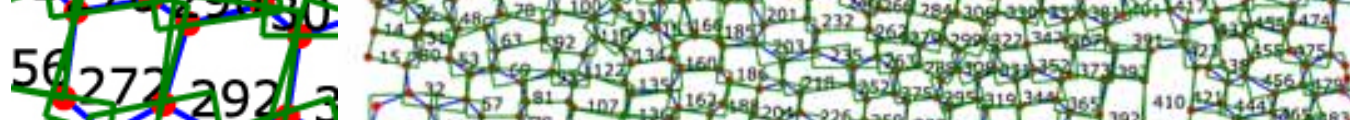

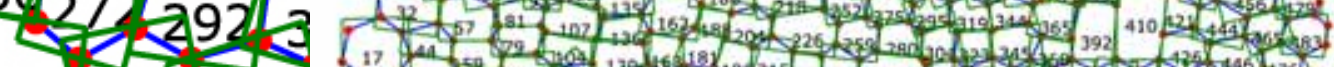

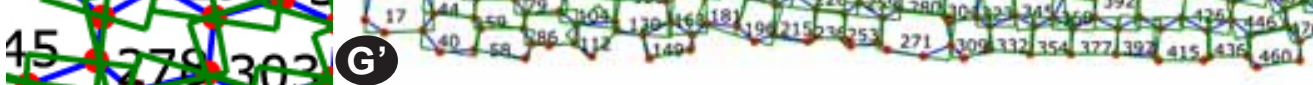



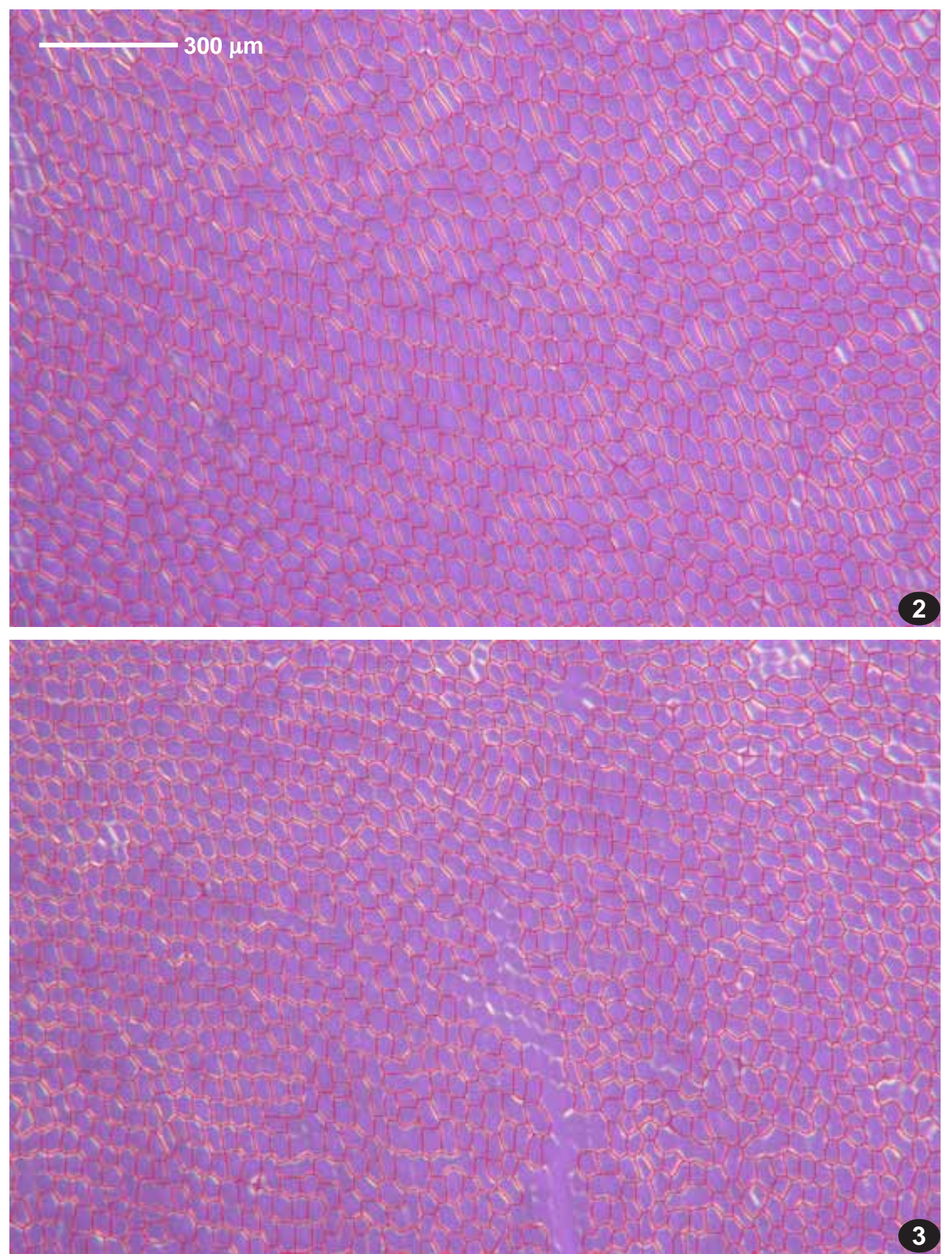

Figs. 2-3. (2) Cells of Mnium spinosum Altai, Ignatov 0/1534 (MHA); and (3) Mnium spnulosum Altai, Ignatov, 0/1535 (MHA): cell net in polarized light with digitized cell outlines. 


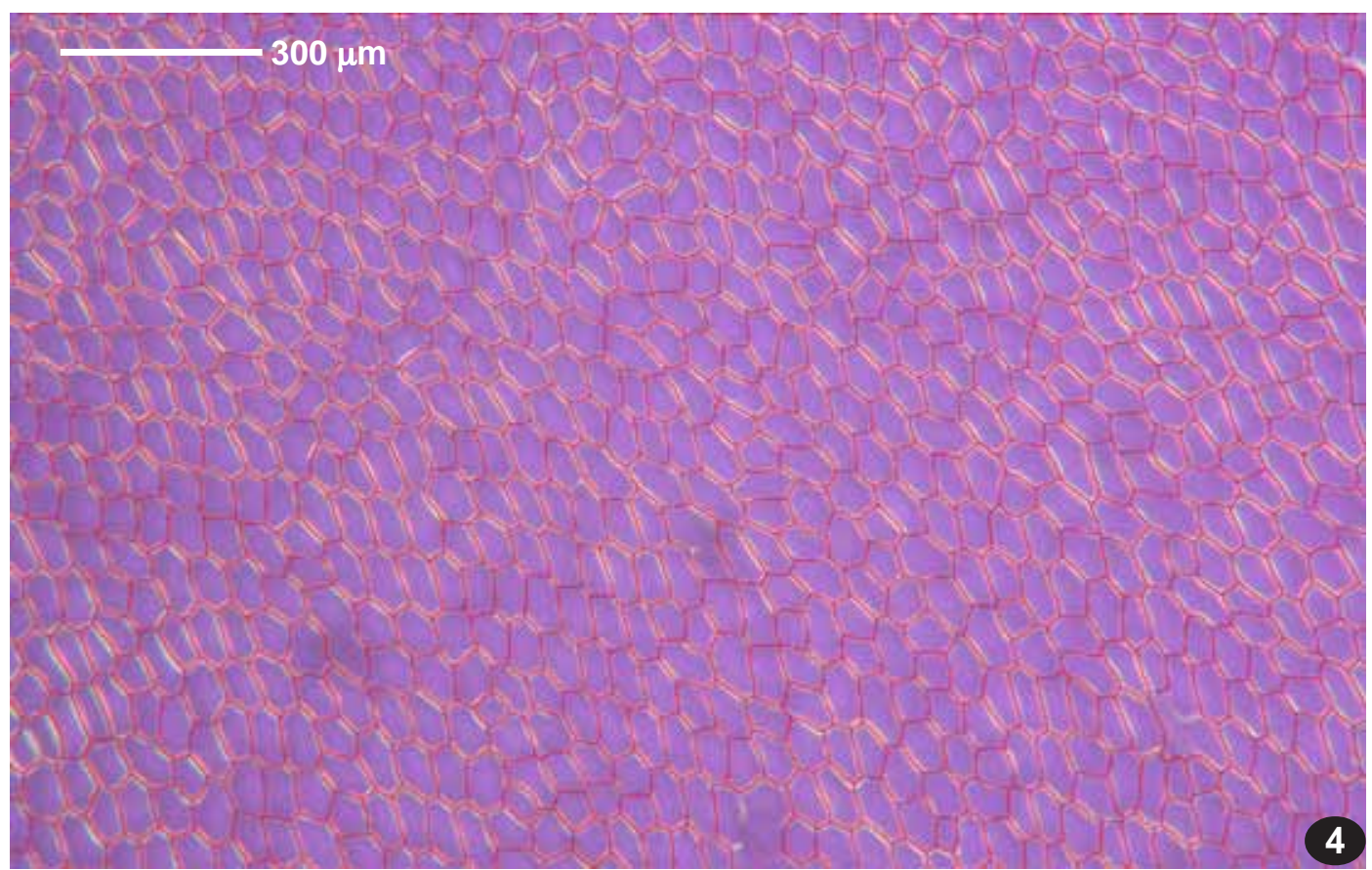

Fig. 4. Cells of Mnium spinosum Karelia (Maximov \& Maksimova, 29.V.2002, PTZ, MHA): cell net in polarized light with digitized cell outlines.

correspondingly. There are also many characters that allow separation of these species from other superficially similar members of the genus, so any identification mistakes are ruled out in our study.

\section{COMPARISON OF MNIUM SPINOSUM} AND M. SPINULOSUM

Despite a certain difference in cell dimensions in these species (Table 2), three of the four authors who provided concrete data on it agree that cells in M. spinosum are larger than in $M$. spinulosum, while Limpricht' measurements found them subidentical.

The measurement involves three specimens of each species, from geographically separated regions (the Caucasus, the Altai and Russian Far East).
At least two leaves from each of at least two shoots were used for photography and measurements, so 12-30 pictures (cf. Figs. 2-4) were taken for width and length calculation.

Graphs for these three pairs of specimens are shown in Fig. 5, depicting distribution curves smoothened by Gaussian function, where $\sigma=5 \mu \mathrm{m}$ for cell width and length, and $\sigma=50 \mu \mathrm{m}^{2}$ for cell squares.

$$
F(x)=\sum_{n=1}^{n_{M+1}}\left[\frac{1}{\sigma \cdot \sqrt{2 \pi}} \cdot e^{\frac{-\left(x-t_{n}\right)}{2 \cdot \sigma^{2}}}\right.
$$

The results from Fig. 5 indicate that the laminal cells of $M$. spinosum is larger in specimens from Far east, but equal in Caucasus and even smaller in Altai.

Table 2. Comparison of published data on cell dimensions in Mnium spinosum and M. spinulosum, in $\mu \mathrm{m}$.

Smith, 2004

Crum \& Anderson, 1981

Lawton, 1971

Limpricht, 1885-1904

Noguchi 1989

Hallingback et al., 2008

Ignatov \& Ignatova, 2003

Koponen, 1980

\section{M. spinosum}

16-40 wide

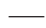

0.022-0.028 mm

$15-22 \times 30-35$

12-22 wide

$21-27 \times 35-50$

$14-19 \times 28-43 *$

\section{M. spinulosum}

\section{$21-25(-35)$}

near costa $30-40$, towards the margin $18-25$

0.02-0.03 mm

$15-22 \times 20-30$

$17-25 \times 20-30$

$19-35 * *$ - measured from pictures 

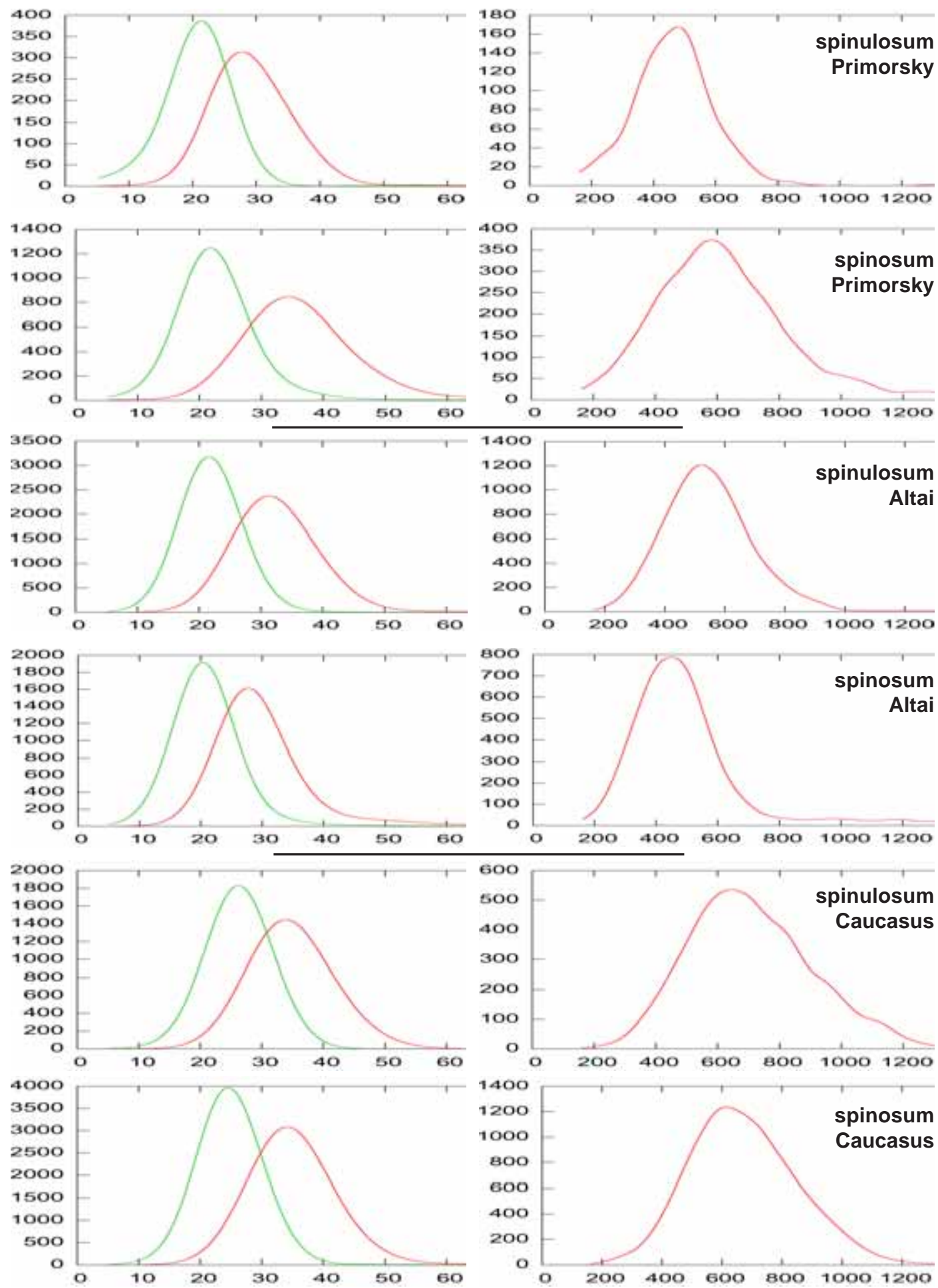

Fig. 5. Three pairwise comparisons of Mnium spinulosum and M. spinosum from Primorsky Territory (Russian Far East), Altai (southern West Siberia) and Caucasus. Left column pictures show distribution of leaf cell width (left peak/green) and length (right peak/red), in $\mu \mathrm{m}$; right column gives distributions of square (in sq. $\mu \mathrm{m})$. Axe $\mathrm{Y}$ is number of measured cells. Distribution curves smoothened by Gaussian function (cf. page 91). 

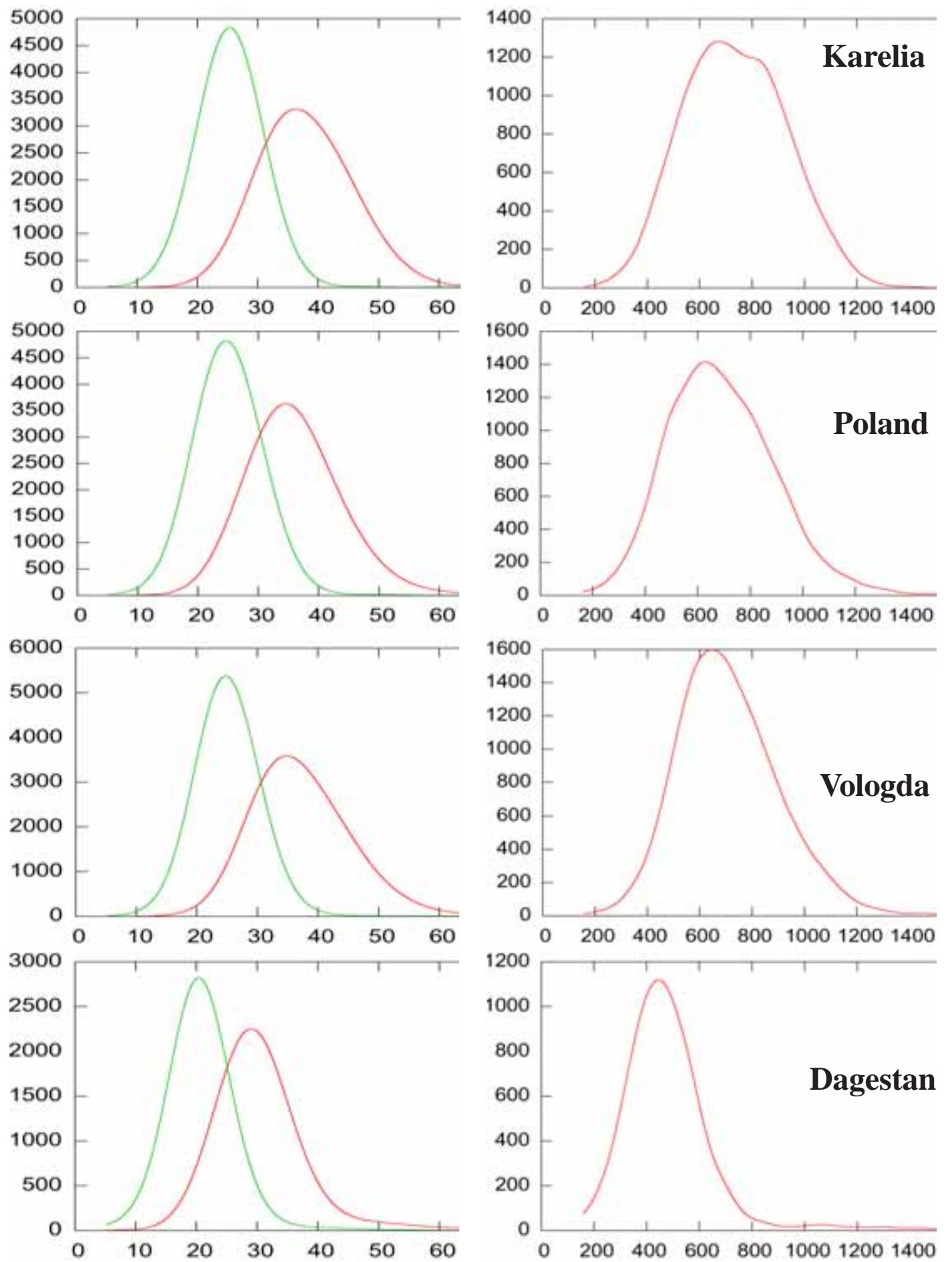

Fig. 6. A comparison of Mnium spinulosum from four localities. Left column pictures show distribution of leaf cell width (left peak/green) and length (right peak/red), in $\mu \mathrm{m}$; right column gives distributions of square (in sq. $\mu \mathrm{m}$ ). Axe Y is number of cells. Distribution curves smoothened by Gaussian function (cf. page 91). 

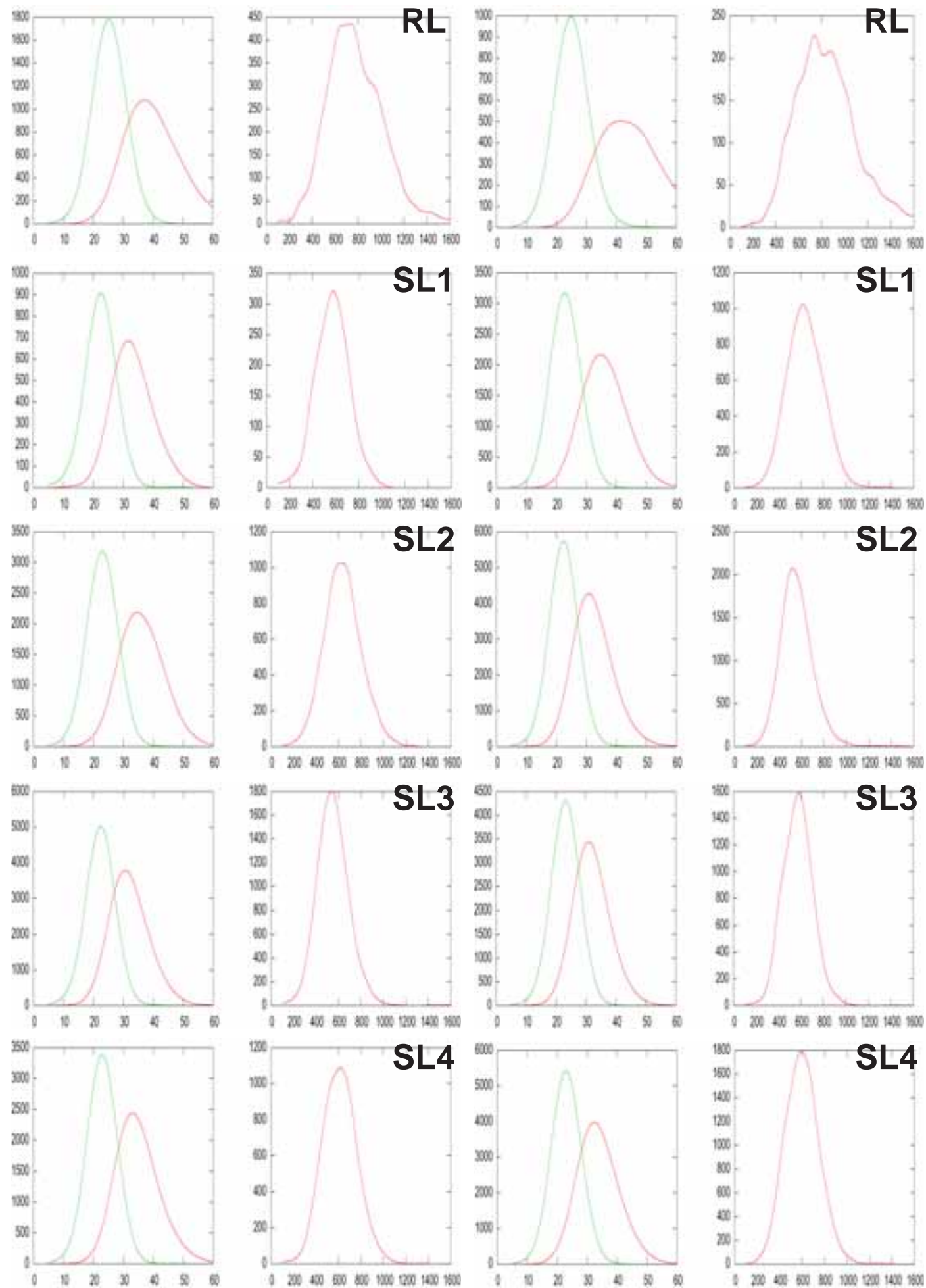

Fig. 7. Mnium spinosum (Archangelsk). Distribution of cell width (left peak/green) and length (right peak/ red) and square (graphs with single peak), for five leaves (one from upper rosette RL, and four stem leaves SL14, from rosette to mid-stem) of two shoots from the same specimen. Data for these graphs are shown in Tables 3-4. 
Tables. 3-4. Cell measurements in leaves of two shoots of Mnium spinosum (Archangelsk). Data for two shoots is presented in two tables, in the left and right sides of page. Lines provide data for individual pictures for rosette leaves (RL) and four stem leaves (SL1-4, in order from top to middle part of stem). Individual photographs (example in Fig. 4) are marked by letters; they were taken in order from lower part of leaf (however excluding basal part with obviously elongate cells) towards leaf apex considering minimal overlapping with previous picture, and in broad leaves by two (closer to costa and then closer to margin) at the same distance from base. Column abbreviations are as follow: $\mathrm{n}$ - number of cells per picture; $\mathrm{x}$ - length, $\mathrm{y}-$ width, $\mathrm{s}-\mathrm{square}, \mathrm{d}$ - dispersion. The data are presented as graphs in Fig. 7. Note the considerably larger cells in rosette leaves.

\begin{tabular}{|c|c|c|c|c|c|c|c|c|c|c|c|c|c|c|c|}
\hline & $\mathrm{n}$ & $\mathrm{A}$ & d & $\mathrm{y}$ & d & $\mathrm{s}$ & d & & $\mathrm{n}$ & $\mathrm{X}$ & d & $\mathrm{y}$ & d & $\mathrm{s}$ & $\mathrm{u}$ \\
\hline LA & 325 & 44.87 & 098 & 7.12 & 653 & 29.0 & 59.83 & RLA & 186 & 46.97 & .754 & 25.38 & 5.861 & 906.1 & 72.83 \\
\hline LB & 553 & .10 & 186 & 5.97 & 668 & 7.1 & 10.61 & LB & 227 & 45.99 & 7.594 & .18 & 4.630 & 61.5 & , \\
\hline LC & 550 & 3.10 & 347 & 5.79 & 196 & 54.1 & 91.67 & RLC & 353 & 41.11 & 7.800 & 3.97 & 4.450 & 58.3 & 5.58 \\
\hline LD & 376 & 3.11 & 740 & 3.88 & .473 & 696.2 & 75.06 & RLD & 249 & 48.60 & 7.829 & 5.09 & 4.935 & 84.2 & 51.56 \\
\hline LE & 339 & 4.54 & 386 & 8.60 & 863 & 83.3 & 63.40 & RLE & 268 & 45.82 & 7.364 & 6.90 & .606 & 56.5 & 52.58 \\
\hline $\mathrm{F}$ & 301 & .29 & 746 & 7.58 & 551 & 57.1 & 32.60 & RLF & 331 & 39.49 & 7.470 & 6.14 & 480 & 88.4 & 97.57 \\
\hline \multirow[t]{2}{*}{ LG } & 363 & .08 & 310 & 5.77 & 579 & 95.5 & 30.00 & & & & & & & & \\
\hline & & & & & & & & SL1 A & 719 & 39.51 & 7.218 & 2.88 & 666 & 88.9 & 32.73 \\
\hline $1 \mathrm{~A}$ & 676 & 39.67 & 023 & 4.72 & 154 & 755.2 & 92.27 & SL1 B & 669 & 36.43 & 6.574 & 4.37 & 839 & 3.4 & 170.12 \\
\hline $1 \mathrm{~B}$ & 667 & 38.44 & 938 & 4.85 & 094 & 741.4 & 81.58 & $1 \mathrm{C}$ & 648 & 40.32 & 6.967 & 2.58 & .397 & 13.0 & 81.16 \\
\hline $1 \mathrm{C}$ & 650 & 9.45 & 200 & 23.53 & 750 & 727.1 & 68.07 & $1 \mathrm{D}$ & 707 & 35.67 & 5.772 & 25 & 80 & 61.0 & 86 \\
\hline $1 \mathrm{D}$ & 654 & 5.89 & 6.331 & 24.18 & .564 & 666.6 & 55.64 & L1 E & 730 & 37.19 & 6.699 & 56 & 774 & 00.8 & 4.81 \\
\hline $1 \mathrm{E}$ & 592 & 37.52 & .063 & 22.47 & 677 & 656.4 & 63.66 & $1 \mathrm{~F}$ & 633 & 35.06 & 5.782 & .19 & 73 & 1.7 & 155.18 \\
\hline $1 \mathrm{~F}$ & 474 & 4.73 & 5.182 & 4.37 & 885 & 646.6 & 48.93 & SL1 G & 532 & 35.22 & 6.440 & 23.16 & 3.864 & 24.0 & 59.61 \\
\hline 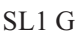 & 536 & .70 & 226 & 2.49 & 908 & 616.3 & 47.35 & & & & & & & & \\
\hline \multirow[t]{2}{*}{ L1 H } & 445 & 89 & .818 & 23.16 & 788 & 616.6 & & & 763 & & & & & & \\
\hline & & & & & & & & SL2 B & & & 5.970 & & 33 & & \\
\hline $2 \mathrm{~A}$ & 757 & 5.78 & .888 & 23.21 & 631 & 634.0 & 162.03 & SL2 C & 771 & 35.59 & 6.728 & 41 & 446 & .7 & 61.79 \\
\hline $2 \mathrm{~B}$ & 644 & .96 & .032 & 2.97 & .368 & 584.7 & 7 & L2 D & 8 & 3 & 5.182 & 70 & 89 & 9 & 88 \\
\hline $2 \mathrm{C}$ & 685 & 5.74 & 652 & 4.39 & .081 & 657.4 & 97 & L2 E & 7. & 36 & 6.486 & 54 & 15 & .2 & 28 \\
\hline $2 \mathrm{D}$ & 600 & 2.82 & 527 & 3.17 & 325 & 588.3 & 3 & L2 F & 8 & 3 & 4.949 & 25 & 14 & 6 & 68 \\
\hline $2 \mathrm{E}$ & 41 & .72 & 08 & 4.00 & 6 & .1 & & G & 5 & & 5. & & & .3 & 08 \\
\hline $2 \mathrm{~F}$ & 780 & 1.49 & 81 & 10 & 566 & 566.6 & 15 & $\mathrm{H}$ & 617 & & 4.358 & & 39 & .6 & 19 \\
\hline $2 \mathrm{G}$ & 604 & 3.21 & 985 & 2.63 & 006 & 582.1 & 1 & 2 I & 739 & 78 & 5.387 & & & .5 & \\
\hline $2 \mathrm{H}$ & 656 & .65 & 800 & 2.93 & 81 & .3 & & $2 \mathrm{~J}$ & 567 & & & & & & .15 \\
\hline 2 I & 376 & .64 & 141 & 2.09 & 292 & 562.2 & 43 & SL2 L & 624 & & 5.708 & & 987 & & 29 \\
\hline $2 \mathrm{~J}$ & 496 & .58 & 368 & 3.13 & 405 & 545.7 & 17.41 & & & & & & & & \\
\hline \multirow[t]{2}{*}{ SL2 K } & 679 & .01 & 4.930 & 22.13 & 554 & 548.4 & 125.94 & . & 686 & 34.89 & 6.446 & 6 & 05 & .5 & 141.24 \\
\hline & & & & & & & & & & & & & & & \\
\hline 3 & 80 & . & 575 & .96 & 3.834 & 4.8 & 1 & SL3 C & 722 & 32 & 4.945 & & 14 & & 15 \\
\hline $3 \mathrm{~B}$ & 665 & 3.25 & 76 & 4.25 & 4 & 716.8 & & L3 D & 78 & 34.17 & 33 & 06 & 5 & & 91 \\
\hline $3 \mathrm{C}$ & 744 & .09 & 54 & 3.94 & 34 & 627.9 & 147.89 & $3 \mathrm{E}$ & 76 & 3 & 6 & 67 & 3 & 6 & 3.79 \\
\hline 3 & 627 & . & 14 & 3 & 467 & 67 & & $\mathrm{~F}$ & 796 & & 7 & & 86 & & 37 \\
\hline $3 \mathrm{E}$ & 733 & 22 & 779 & 55 & 2 & 7 & & L3 G & 61 & & 27 & & 13 & & .71 \\
\hline $3 \mathrm{~F}$ & 542 & & 573 & & 9 & 59 & & SL3 H & 654 & 32.22 & 4.910 & 24.08 & 3.184 & 603.9 & 128.01 \\
\hline \multirow[t]{2}{*}{ SL3 G } & 641 & 35.96 & 6.890 & 23.26 & 932 & 628.1 & 18 & & & & & & & & \\
\hline & & & & & & & & & & & & & & & \\
\hline 4 & 518 & 34.36 & 258 & 3.28 & 555 & & & & 587 & & 29 & & 94 & 7.1 & 7.86 \\
\hline $4 \mathrm{~B}$ & 734 & 4.43 & 6.408 & 23.57 & 688 & 630.3 & 59.81 & $4 \mathrm{C}$ & 613 & 35.47 & 6.062 & 23.86 & 3.463 & 5.7 & 42.51 \\
\hline $4 \mathrm{C}$ & 621 & 32.93 & 5.296 & 24.70 & 375 & 631.8 & 45.71 & L4 D & 722 & 35.42 & 6.157 & 4.77 & 3.709 & 681.7 & 162.02 \\
\hline $4 \mathrm{D}$ & 664 & 34.11 & 5.858 & 24.13 & .759 & 643.6 & 52.14 & SL4 E & 634 & 32.29 & 5.165 & 23.98 & 3.437 & 0.9 & 141.07 \\
\hline $4 \mathrm{E}$ & 653 & .56 & 853 & & 7 & & & $4 \mathrm{~F}$ & 59 & & 6.186 & & 4.143 & & 1.92 \\
\hline 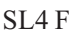 & 658 & 32.16 & 4.916 & 24 & 3.1 & & & $4 \mathrm{G}$ & 474 & & 16 & & 49 & & 19 \\
\hline \multirow[t]{4}{*}{ SL4 G } & 33 & 33.27 & 193 & 24.61 & 3.568 & 632.0 & 146.20 & SL4 H & 733 & 01 & 6.160 & & 77 & & 2.04 \\
\hline & & & & & & & & & & & & & & & \\
\hline & & & & & & & & & 62 & & & & & 5.2 & 38.86 \\
\hline & & & & & & & & SI & 718 & 34.48 & 6.559 & 24.22 & 3.720 & 650.5 & 164.6 \\
\hline
\end{tabular}




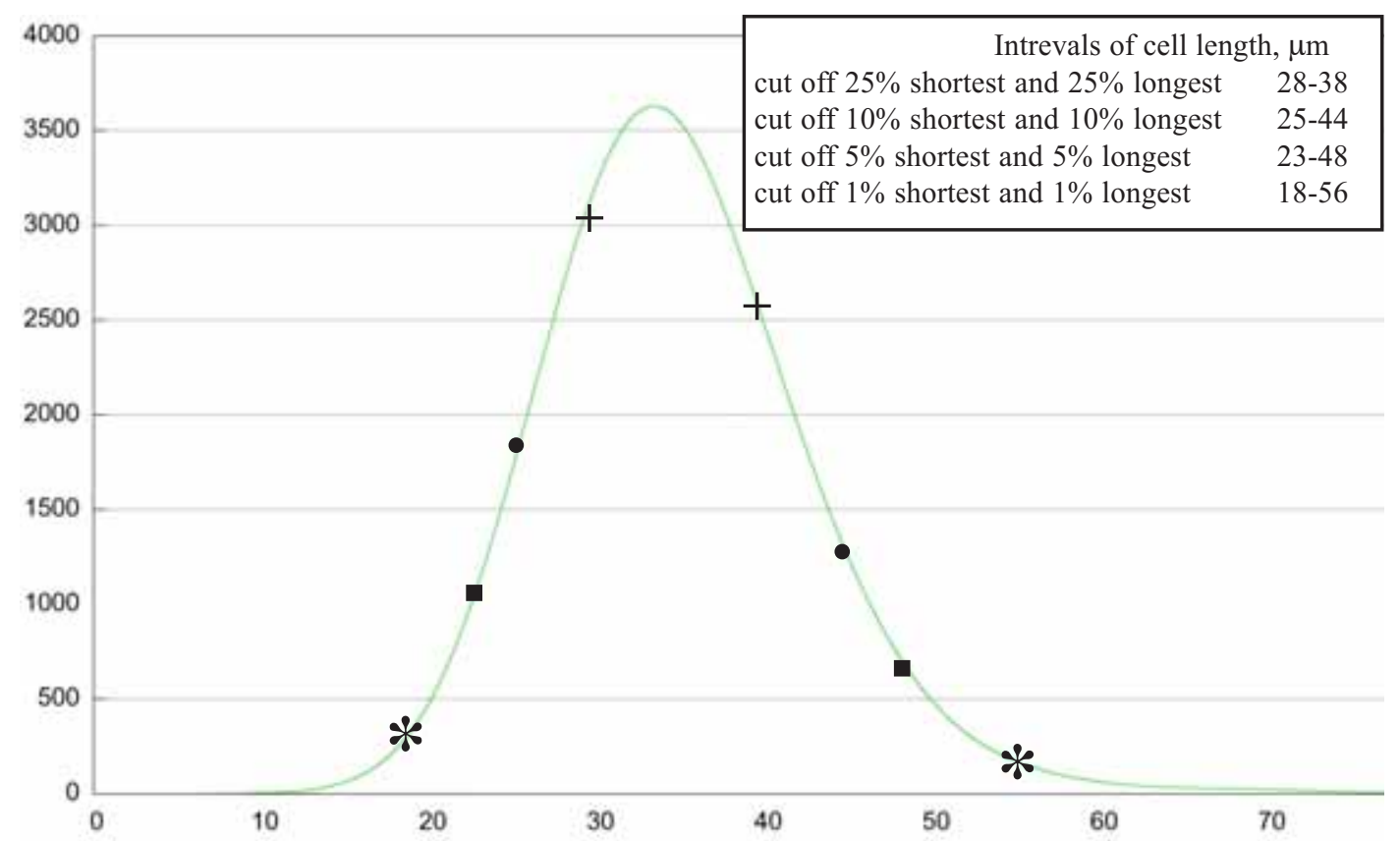

Fig. 8. Distribution of leaf cell lengths (above) and widths (below) of the Karelian specimen of Mnium spinosum (7326 cells measured, one of picture in Fig. 4). Axe X - $\mu$ m; Axe Y - number of cells. Graphs show distribution curves smoothened by Gaussian function (cf. page 91), with intervals of most common length and width, after cut off $25 \%$ shortest/narrowest and $25 \%$ longest/widest cells (crosses), 10\% (solid circles), 5\% (solid rectangulars) and 1\% (asterisk). Intervals of the most common lengths and widths in $\mu \mathrm{m}$ shown within graphs.

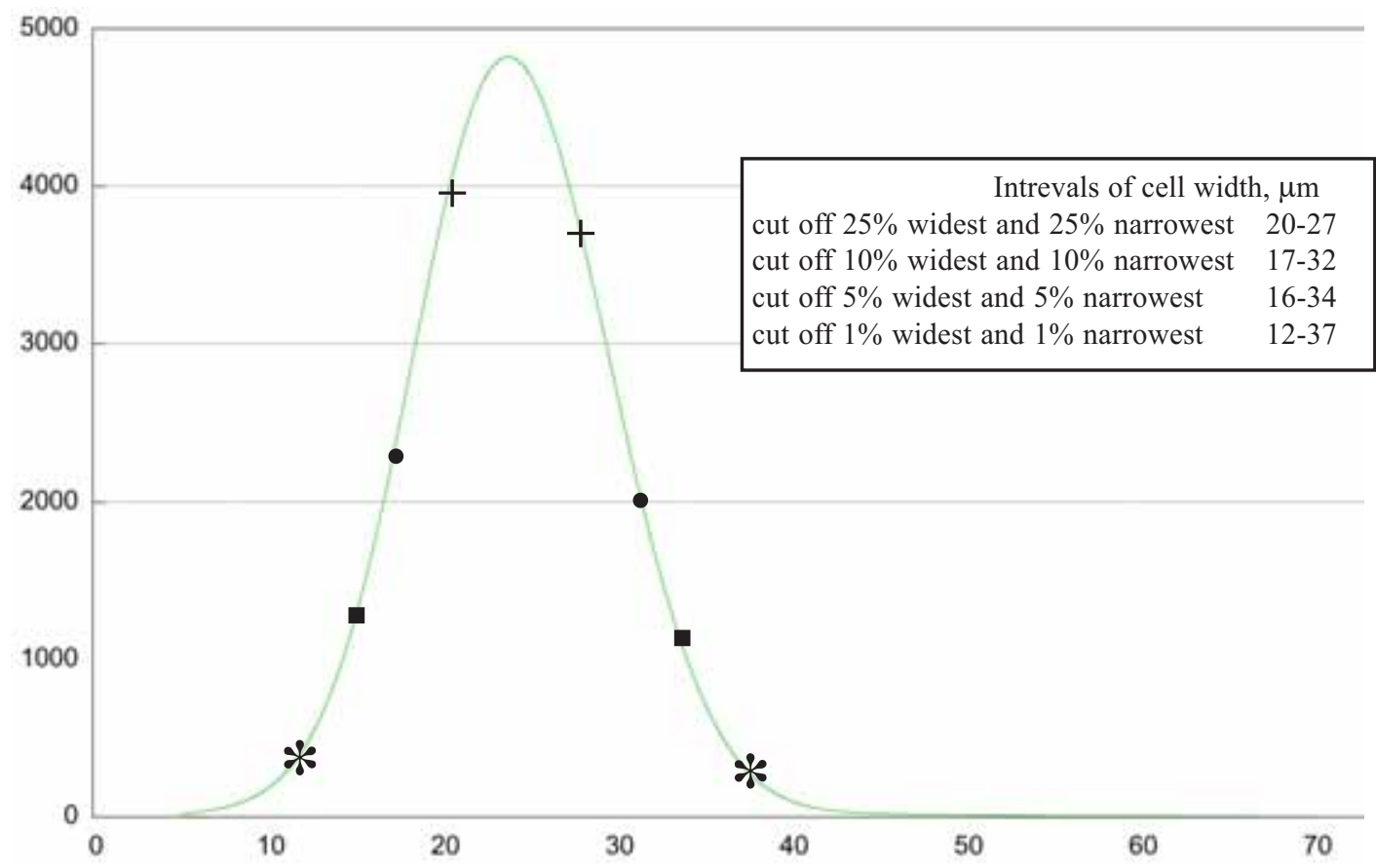




\section{LEAF CELL VARIATION IN MNIUM SPINOSUM}

Measurements of additional specimens of $M$. spinosum from different parts of Russia and Central Europe (from where M. spinulosum was not readily available) reveal an even greater variation (Fig. 6).

Plants from a wet boreal conifer forest from the middle elevation in Central Europe (Poland) and from northern part of Russia (Karelia and Vologda) have much bigger cells comparatively with plants from a relatively dry Betula forest in Dagestan.

The latter may be correlated with the quite xeric climate of the latter area. However, another explanation is also possible. Plants from Dagestan collection have only male shoots, and the subapical leaf rosette was not formed in them.

The comparison of cells in leaves of subapical rosette and of those from the middle part of stem was done using plants from Arkhangelsk Province in Northern European Russia.

Measurements in two shoots (Fig. 7, Tables 3-4) show that cells in rosette leaves are larger, thus confirming ordinary observations from the routine practice of mass identification of collections (likely familiar to any bryologist who always need to know which leaves to detach and measure for proper determination in the course of a routine identification process).

The variation of cell length and width in different specimens appeared to be greater than expected, at least greater than reported in handbooks and floras (cf. Table 2). Thus the question arises which values should be used for standard morphological descriptions. A possible approach can be obtained from cutting off 10,5 and 1 percent of cells with maximal and minimal values of their width and length (Fig. 8).

The data were obtained from the Karelian specimen (cf. Figs. 4, 6) which had one of the maximal number of measureed cells, 7326, and represented likely the most optimally developed plant, at least its cells were one of the largest. Cutting off $2 \%$ of cells with marginal values of width and length, and even $10 \%$ of such cells, provided an interval that looked too broad to be practical, at least for ordinary purposes, like routine identification. It looks that some of the published intervals correspond more or less to the most common cell size (between 50 and 80 percent of cells).

It should be kept in mind, of course, that the graphs in Fig. 8 illustrate variation in only one specimen, and the adding of plants from other regions, as well as involving in examination not fully developed plants will expand the variation intervals with respective cuttings off marginal values.

Summing up, it seems that the computerized mass measurements of moss laminal cells supply data considerably different from those obtained by an ordinary measurements of 'typical' cells. The computrized measurements open a path to better understanding of variation within single leaf, different leaves of individual plants, as well as within and among populations.

\section{LITERATURE CITED}

CRUM, H.A. \& L.E. ANDERSON 1981. Mosses of Eastern North America (Vol. 1-2). - New York, Colombia University Press, $1328 \mathrm{pp}$.

HALLINGBÄCK, T., N. LÖNNELL \& H. WEIBULL 2008. Bladmossor: kompaktmossor-kampmossor: Bryophyta: Anoectangium-Orthodontium. - Uppsala, Nationalnyckeln till Sveriges flora och fauna. ArtDatabanken, Sveriges lantbruksuniversitet, $504 \mathrm{pp}$.

HEDENÄS, L. 1993. Field and microscope keys to the Fennoscandian species of the Calliergon-Scorpidium-Drepanocladus complex, including some related or similar species. Marsta (Sweden), Biodetector AB. 79 pp.

HEDENÄS, L. 2003. The European species of the CalliergonScorpidium-Drepanocladus complex, including some related or similar species. - Meylania 28: 1-116.

HEDWIG, J. 1801. Species Muscorum Frondosorum Descriptiae et tabulis Aeneis lxxvii Coloratis Illustratae. - Joannis Ambrosii Barthii. Leipzig, 352 pp. +77 tabs.

[IGNATOV, M.S. \& E.A. IGNATOVA] ИГНАТОВ M.C., Е.A. ИГНАТОВА 2003-2004. Флора мхов средней части европейской России. Т. 1-2. - [Moss flora of the Middle European Russia. Vol. 1] M., KMK [Moscow, KMK]: 960 pp.

[IVANOV, O.V. \& M.S. IGNATOV] ИВАНОВ O.В., М.С. ИГНАТОВ 2012. Цифровое представление изображений клеточных сетей растений. - [Digitizing of cell nets in plants] (Msc. submitted in Cytologia (Moscow))

KOPONEN, T. 1980. A synopsis of Mniaceae (Bryophyta). IV. Taxa in Europe, Macaronesia, NW Africa and the Near East. - Ann. Bot. Fennici 17: 125-162.

LAWTON, E. 1971. Moss Flora of the Pacific Northwest. Nichinan, Hattori Bot. Lab., xiii +362 pp. $+195 \mathrm{pl}$.

LIMPRICHT, K.G. 1885-1904. Die Laubmoose. - In: Rabenhorst, L. Kryptogamen-flora von Duetschland, Oesterreich und der Scheiz. Bds. 1-3. 836, 853, 864 s. 
LINDBERG, S.O. \& H.W. ARNELL 1890. Musci Asiae Borealis. - Kongl. Svenska Vetensk.-Akad. Handl. 23(10): 1-163.

NOGUCHI, A. 1989. Illustrated moss flora of Japan. Pt. 3 Hattori Botanical Laboratory, Nichinan: 489-742.

NOGUCHI, A. 1992. Illustrated moss flora of Japan. Pt. 5 Hattori Botanical Laboratory, Nichinan: 1013-1253.

SMITH, A.J.E. 2004. The moss flora of Britain and Ireland. 2 ed. - Cambridge, Cambridge University Press, 1012 pp.

Appendix. Specimen information Mnium spinosum

Altai Ignatov \#0/1534 (MHA)

Arkhangelsk Ignatov 2.VIII.1988 (MHA)

Caucasus (Karachaevo-Cherkessiya, Arkhyz)
Ivanov 2149 (MHA)

Dagestan Ignatov\&Ignatova \#09617 (MHA)

Karelia Maksimov \& Maksimova, 29.V.2002 (MHA ex PTZ)

Poland Ignatov\&Ochyra 10.III.1995(MHA)

Primorsky Ignatov \#07-226 (MHA)

Vologda Ignatov\&Ignatova 19.VIII.2001 (MHA)

\section{Mnium spinulosum}

Altai Ignatov \#0/1535 (MHA)

Caucasus (Karachaevo-Cherkessiya, Arkhyz) Ivanov 2253 (MHA)

Primorsky Ignatov \#07-549 (MHA) 